Correspondence

Patrick J. Keeling

pkeeling@interchange.ubc.ca

\section{Molecular and morphological analysis of the family Calonymphidae with a description of Calonympha chia sp. nov., Snyderella kirbyi sp. nov., Snyderella swezyae sp. nov. and Snyderella yamini sp. nov.}

\author{
Gillian H. Gile, ${ }^{1} \dagger$ Erick R. James, ${ }^{1}$ Rudolf H. Scheffrahn, ${ }^{2}$ \\ Kevin J. Carpenter, ${ }^{1} \ddagger$ James T. Harper ${ }^{1,3}$ and Patrick J. Keeling ${ }^{1}$ \\ ${ }^{1}$ Department of Botany, University of British Columbia, 3529-6270 University Boulevard, \\ Vancouver, BC V6T 1Z4, Canada \\ ${ }^{2}$ University of Florida Research \& Education Center, 3205 College Avenue, Davie, \\ FL 33314, USA \\ ${ }^{3}$ Department of Biology, Douglas College, 700 Royal Avenue, New Westminster, \\ BC V3M 5Z5, Canada
}

\begin{abstract}
Calonymphids are a group of multinucleate, multiflagellate protists belonging to the order Cristamonadida (Parabasalia) that are found exclusively in the hindgut of termites from the family Kalotermitidae. Despite their impressive morphological complexity and diversity, few species have been formally described and fewer still have been characterized at the molecular level. In this study, four novel species of calonymphids were isolated and characterized: Calonympha chia and Snyderella yamini spp. nov., from Neotermes castaneus and Calcaritermes nearcticus from Florida, USA, and Snyderella kirbyi and Snyderella swezyae, spp. nov., from Calcaritermes nigriceps and Cryptotermes cylindroceps from Colombia. Each of these species was distinguished from its congeners by residing in a distinct host and by differences at the molecular level. Phylogenetic analyses of small subunit (SSU) rDNA indicated that the genera Calonympha and Stephanonympha were probably not monophyletic, though the genus Snyderella, previously only represented by one sequence in molecular analyses, appeared with these new data to be monophyletic. This was in keeping with the traditional evolutionary view of the group in which the morphology of the genus Snyderella is considered to be derived, while that of the genus Stephanonympha is ancestral and therefore probably plesiomorphic.
\end{abstract}

\section{INTRODUCTION}

Calonymphids are multinucleate, multiflagellate, anaerobic or microaerophilic protists that live in the hindgut of drywood or dampwood termites (family Kalotermitidae). They belong to the Parabasalia, a group of symbiotic (mutualistic and parasitic) protists that includes the human pathogen Trichomonas vaginalis. In parabasalids,

†Present address: Department of Biochemistry and Molecular Biology, Dalhousie University, 5850 College Street, Room 9-G1, Halifax, NS B3H $1 \times 5$, Canada.

‡Present address: Physical and Life Sciences Directorate, Lawrence Livermore National Laboratory, L-231, 7000 East Ave, Livermore, CA 94551, USA.

Abbreviations: ML, maximum-likelihood; SEM, scanning electron microscopy; SSU, small subunit; TEM, transmission electron microscopy.

The GenBank/EMBL/DDBJ accession number for the nuclear SSU and mitochondrial SSU and COIl sequences determined in this study are HO215836-HO215844 and HO.593144-HO593145. the basic mastigont system consists of three anteriorly directed flagella and one recurrent flagellum (Brugerolle, 1991), connected to the Golgi apparatus by parabasal fibres and typically associated with an axostyle (Brugerolle, 1991; Cepicka et al., 2010). Certain parabasalid lineages, found exclusively in the hindguts of lower termites and woodeating cockroaches of the genus Cryptocercus, have elaborated on this basic mastigont organization and bear hundreds or thousands of flagella (Brugerolle \& Lee, 2000). In the family Calonymphidae, nuclei and their associated axostyles have also multiplied, a characteristic that distinguishes them from the independently elaborated hypermastigote lineages (Kirby, 1947; Ohkuma et al., 2005; Cepicka et al., 2010). Calonymphid nuclei are either each associated with a mastigont system, as a karyomastigont, or are free in the cytoplasm, leaving akaryomastigonts at the cell's periphery. The presence and relative numbers of karyo- and akaryomastigonts have been used to define genera in this group (Brugerolle \& Lee, 2000). 
Since the family Calonymphidae was proposed (Grassi \& Foà, 1911) to include the genera Calonympha and Microrhopalodina (now known to be an oxymonad genus), nine additional calonymphid genera have been described and molecular phylogenetic analyses have shown that the group consists of two independent lineages (termed the Calonympha-group and Coronympha-group, Cepicka et al., 2010). The genera Coronympha and Metacoronympha were previously included in the family Calonymphidae due to their multiple nuclei and flagella (Kirby, 1939, 1947). However, the axostyles in these genera do not form a bundle in the centre of the cell and molecular phylogenetic analyses have shown they branch independently from the Calonympha-group (Kirby, 1929, 1939; Gerbod et al., 2002; Noël et al., 2007; Harper et al., 2009), so they should no longer be considered to be calonymphids. In addition, the genus Metacoronympha was recently determined to be a life cycle stage of the genus Coronympha (Harper et al., 2009) and was therefore dissolved.

Calonymphid genera for which molecular data are available are Stephanonympha, Calonympha and Snyderella. These are also the best-studied morphologically, with several described species in each genus. In the genus Stephanonympha, all mastigont systems are karyomastigonts and they are arranged in a loose spiral or spirals extending from the cell apex (Janicki, 1911). The genus Calonympha also has karyomastigonts, in one or two turns of a loose spiral, but these are posterior to a larger number of akaryomastigonts (Foà, 1905). The genus Snyderella exhibits only akaryomastigonts and the nuclei are randomly distributed in the cytoplasm (Kirby, 1929). In each of these genera, the axostyle associated with each mastigont extends towards the centre axis of the cell where the strands form a bundle that proceeds towards or through the cell's posterior. Molecular data from six species and unnamed strains of these three genera so far do not address whether the genus Snyderella is monophyletic, but they do suggest that the genera Calonympha and Stephanonympha may not be. Together these three calonymphid genera form a clade in small subunit (SSU) rRNA trees (Gerbod et al., 2002; Noël et al., 2007; Noda et al., 2009).

Currently, the kalotermitid species whose symbionts have not been studied significantly outnumber those whose have (Yamin, 1979), suggesting that the bulk of calonymphid diversity has yet to be observed and many more species await description. Here, we have contributed to addressing this deficiency by describing and providing SSU rRNA sequences for four novel species of calonymphids from four different termite hosts, as well as scanning electron microscopy (SEM) analysis of one of the novel species.

\section{METHODS}

Cell isolation, DNA extraction, PCR and sequencing. Several individuals of Neotermes castaneus and Calcaritermes nearcticus from Florida, USA, and Calcaritermes nigriceps and Cryptotermes cylindroceps from Colombia were collected and maintained at room temperature in the laboratory. Termites were dissected and the hindgut contents were suspended in Trager medium U (Trager, 1934). Individual calonymphid cells were isolated by micropipette and extracted singly or pooled in samples of 4-75 cells for DNA extraction using the Masterpure Complete DNA and RNA Purification kit (Epicentre). DNA was also extracted from the whole gut contents of N. castaneus for environmental PCR. All PCRs used EconoTaq PLUS GREEN (Lucigen).

Parabasalid SSU rRNA gene sequences were amplified using the universal eukaryotic primers PF1 5'-TGCGCTACCTGGTTGATCCTGCC-3' (Keeling, 2002) and FAD4 5'-TGATCCTTCTGCAGGTTCACCTAC-3' (Medlin et al., 1988; Deane et al., 1998). This primer pair amplifies nearly the entire SSU: against the human $18 \mathrm{~S}$ rRNA reference sequence NR_003286.2, PF1 binds to the first $18 \mathrm{nt}$ and includes $5 \mathrm{nt}$ upstream, while the FAD4 binding region ends just $3 \mathrm{nt}$ before the $3^{\prime}$ end of the gene. The SSU from Snyderella yamini sp. nov. was amplified using a nested reaction with primers PF1 and FAD4 followed by GGF 5'-CTTCGGTCATAGATTAAGCCATGC-3' and GGR 5'-CCTTGTTACGACTTCTCCTTCCTC-3' (this study), which were designed for nested amplification of parabasalid SSU. PCR conditions included a 3 min denaturation at $95{ }^{\circ} \mathrm{C}$ followed by 30 cycles of $95{ }^{\circ} \mathrm{C}$ for $30 \mathrm{~s}, 55{ }^{\circ} \mathrm{C}$ for $30 \mathrm{~s}$, and $72{ }^{\circ} \mathrm{C}$ for $1 \mathrm{~min} 30 \mathrm{~s}$, then an additional $7 \mathrm{~min}$ at $72{ }^{\circ} \mathrm{C}$. To confirm the identity of the host, termite mitochondrial SSU rRNA sequences were amplified with the primers LR-N-13398 5'-CGCCTGTTTATCAAAAACAT-3' (Simon et al., 1994) and LR-J-13007 5'-TTACGCTGTTATCCCTAA-3' (Kambhampati \& Smith, 1995) and the COII sequence from $N$. castaneus was amplified using A-tLeu 5'-ATGGCAGATTAGTGCAATGG-3' and B-tLys 5'-GTTTAAGAGACCAGTACTTG-3' (Wirth et al., 1999). Cycle conditions were the same as for parabasalid SSU, except that the annealing temperature was lowered to $50{ }^{\circ} \mathrm{C}$ and the extension time was shortened to $1 \mathrm{~min}$.

PCR products were purified using a QIAquick PCR purification kit (Qiagen). Parabasalid SSU sequences were cloned using a Strataclone PCR cloning kit (Agilent Technologies) and sequenced on both strands with a BigDye Terminator v. 3.1 kit (Applied Biosystems). Several clones were sequenced from each parabasalid and the single clone that most closely matched the consensus sequence was chosen for phylogenetic analyses and to submit to GenBank. Mitochondrial SSU and COII were sequenced directly from the purified PCR product, also with BigDye Terminator v. 3.1. All sequences were deposited in GenBank under accession numbers HQ215836HQ215844 and HQ593144-HQ593145 (Table 1).

Phylogenetic analyses. New SSU sequences were added to an existing alignment in MacClade 4.08 (Maddison \& Maddison, 2003). Preliminary phylogenetic analyses (not shown) including representatives of all parabasalid groups confirmed a cristamonad affinity for the novel calonymphids described here. For the final analysis (presented here), trichonymphid and spirotrichonymphid sequences were removed to increase the number of alignable characters, leaving only cristamonad sequences and close tritrichomonad relatives as an outgroup. Sequences were realigned using MAFFT (Katoh et al., 2002). Highly variable and ambiguously aligned regions were removed manually for a final alignment of 48 taxa and 1412 positions ( $83 \%$ of the raw 1692-site alignment). Maximum-likelihood (ML) and Bayesian phylogenetic analyses were performed with RAxML 7.0.4 (Stamatakis, 2006) and MrBayes v3.1.2 (Ronquist \& Huelsenbeck, 2003) respectively, on the freely available Bioportal (http://www. bioportal.uio.no), using the GTR $+\Gamma+\mathrm{I}$ model (with the $\Gamma$ distribution approximated by four rate categories) as specified by Modeltest v3.7 (Posada \& Crandall, 1998) under the Akaike Information Criterion, implemented in PAUP ${ }^{*} 4.0 \mathrm{~b} 10$ (Swofford, 2002). For the ML analysis, support was assessed from 1000 bootstrap replicates. For the Bayesian analysis, two independent chains, sampled 
Table 1. New sequences determined in this study

\begin{tabular}{|lccc|}
\hline Organism & Gene & Length (bp)* & GenBank accession no. \\
\hline Calonympha chia sp. nov. & SSU rDNA & 1528 & HQ215836 \\
Snyderella kirbyi sp. nov. & SSU rDNA & 1590 & HQ215837 \\
Snyderella swezyae sp. nov. & SSU rDNA & 1541 & HQ215838 \\
Snyderella yamini sp. nov. & SSU rDNA & $1482 \dagger$ & HQ593144 \\
Devescovina sp. & SSU rDNA & 1534 & HQ215839 \\
Neotermes castaneus symbiont & SSU rDNA & 1523 & HQ215840 \\
Calcaritermes nigriceps & mitochondrial SSU rDNA & 376 & HQ215841 \\
Calcaritermes nearcticus & mitochondrial SSU rDNA & 375 & HQ593145 \\
Cryptotermes cylindroceps & mitochondrial SSU rDNA & 373 & HQ215842 \\
Neotermes castaneus & mitochondrial SSU rDNA & 379 & HQ215843 \\
Neotermes castaneus & mitochondrial COII & 714 & HQ215844 \\
\hline
\end{tabular}

*Product length does not include primer binding regions.

$\dagger$ Amplified with nested primers.

each 100 generations, were run until they converged (the mean standard deviation of partition frequency values between the chains dropped below 0.01 ) with $25 \%$ of the trees discarded as burn-in. Convergence was reached after 590000 generations and a consensus tree was computed from the 8850 saved trees. This analysis was repeated using identical parameters except that the runs were allowed to continue for 5000000 generations rather than being stopped automatically upon reaching convergence. The consensus tree, built from the 75000 saved trees, had nearly identical topology and posterior probabilities to the consensus of the shorter two runs.

Light and electron microscopy. Hindgut contents suspended in Trager medium $U$ were viewed on a compound microscope (Axioplan 2; Zeiss) using Nomarski interference optics and photographed with a QImaging MicroImager II. Cell isolations were performed on an inverted microscope (Axiovert 200; Zeiss). For SEM, a few drops of hindgut contents in Trager medium $U$ were pipetted onto a Millipore Isopore membrane filter (pore size of 3 or $5 \mu \mathrm{m}$ ) held in a plastic Millipore Swinnex cartridge affixed to a $10 \mathrm{ml}$ syringe. Five millilitres of $2.5 \%$ glutaraldehyde in Trager Medium U buffer were then poured into the syringe and the material was allowed to fix for $30 \mathrm{~min}$. The syringe barrel was then inserted and used to force the glutaraldehyde out of the cartridge. Immediately after, the cartridge was unscrewed from the syringe and $10 \mathrm{ml}$ buffer was pulled into the syringe. The cartridge was then screwed back on and buffer was pushed through for rinsing. This was repeated once or twice before a few millilitres of $1 \% \mathrm{OsO}_{4}$ was pulled into the syringe (with the Swinnex cartridge off) and then placed into contact with the material, which was allowed to fix for $30 \mathrm{~min}$. Following fixation, filters were rinsed with buffer, dehydrated in an ethanol series $(50 \%$, $70 \%, 90 \%, 2 \times 100 \%)$ and critical-point-dried in a $\mathrm{CO}_{2}$ criticalpoint dryer (Autosamdri 815B; Tousimis). Dried filters were affixed to aluminium SEM stubs with double-sided carbon sticky tape and coated with $5 \mathrm{~nm} \mathrm{Au}$ or Au/Pd in a sputter coater $(208 \mathrm{HR}$; Cressington). Samples were examined and photographed in a Hitachi 4700 FESEM at $3-5 \mathrm{kV}$.

\section{RESULTS AND DISCUSSION}

\section{Calonympha chia sp. nov.}

We observed a multinucleate, multiflagellate protist in the hindgut of N. castaneus from Dagny Johnson Park, Key
Largo, Florida, USA (N 25.17608 W 80.36945). The mastigont systems are organized in multiple helical rows from the cell apex. The foremost mastigont systems lack nuclei while the rearmost row or rows of mastigonts are associated with nuclei. An axostylar strand descends from each mastigont to a bundle in the centre of the cell, which reaches or protrudes from the posterior of the cell. In certain SEM images, the axostylar bundle can be seen protruding from the cell's posterior (Fig. 1b, c, f). The observed combination of karyoand akaryomastigonts (which has been confirmed by transmission electron microscopy for a different isolate of the same organism, see below) places this protist in the genus Calonympha (Foà, 1905).

The cell is covered with a glycocalyx (Figs $1 b, 2 b, c)$, which can be seen in high magnification to be made up of a dense, fibrous network (Fig. 2d, e). The surface of the posterior half of the cell, which lacks flagella, is associated with a variety of ectobionts (Fig. 2b-e). Some of these appear to be spirochaetes or possibly bristle-shaped members of the order Bacteroidales (Hongoh et al., 2007), while others are coccoid or rod-shaped cells (Fig. 2b, c). At least three distinct morphotypes of rod-shaped cells can be seen, including long rods with tapered ends (Fig. 2c), long rods with blunt ends (Fig. 2e) and smaller rods that can be as little as $300 \mathrm{~nm}$ in length (Fig. 1b-d).

We amplified the SSU of this organism from DNA extracted from pools of 20-50 cells isolated by micropipette, as well as from environmental PCR of DNA extracted from the entire gut contents. A total of five clones was sequenced on both strands and two independent PCR products were sequenced directly on both strands. All sequences were nearly identical, differing at a total of only seven positions collectively.

The consensus of the five clone sequences was $99 \%$ identical in BLAST alignments to GenBank sequences AM747388 and X97976, both Calonympha sp. from $N$. castaneus, from a culture maintained at the Bundesanstalt 

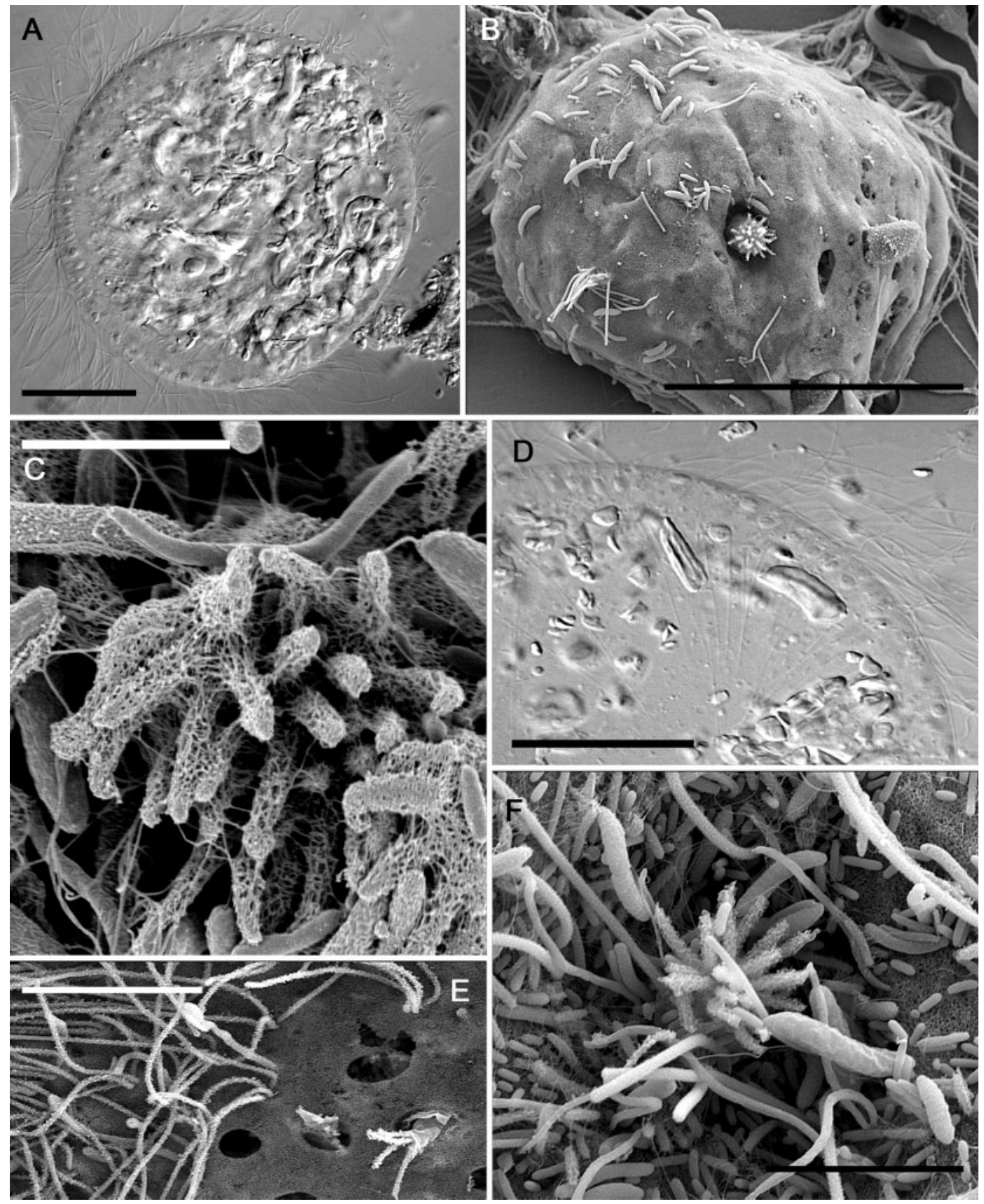

Fig. 1. Overview of Calonympha chia sp. nov. $(a, d)$ Differential interference contrast light micrographs from the posterior of the cell showing ingested wood particles filling the cell and karyomastigonts arranged along the periphery. Axostylar strands are visible in (d). (b, c, e, f) SEM of the cell surface. (b, c, f) Posterior view of the cell with protruding axostylar bundle. (e) Lateral view of the cell. Flagella emerge in groups of four. Bars, a, b, d, $30 \mu \mathrm{m} ; \mathrm{c}, 2.5 \mu \mathrm{m} ; \mathrm{e}, 20 \mu \mathrm{m} ; \mathrm{f}, 5 \mu \mathrm{m}$.

für Materialforschung und -prüfung (BAM), Germany (Branke, 1997; Ikeda-Ohtsubo et al., 2007), which we therefore consider to derive from the same Calonympha species as investigated here. Gut symbionts from this termite strain were investigated by J. Branke before the termite was reliably identified as $N$. castaneus and the record for GenBank accession no. X97976 erroneously specifies
Neotermes jouteli as the host species. There is no doubt, however, that the BAM strain (collected in Cuba) and our $N$. castaneus from Florida, USA, are the same species, based on three lines of evidence. First, the symbiont community of our N. castaneus isolate is identical to that described for the BAM isolate (Branke, 1997; Ikeda-Ohtsubo et al., 2007), while true members of $N$. jouteli have a very different gut 


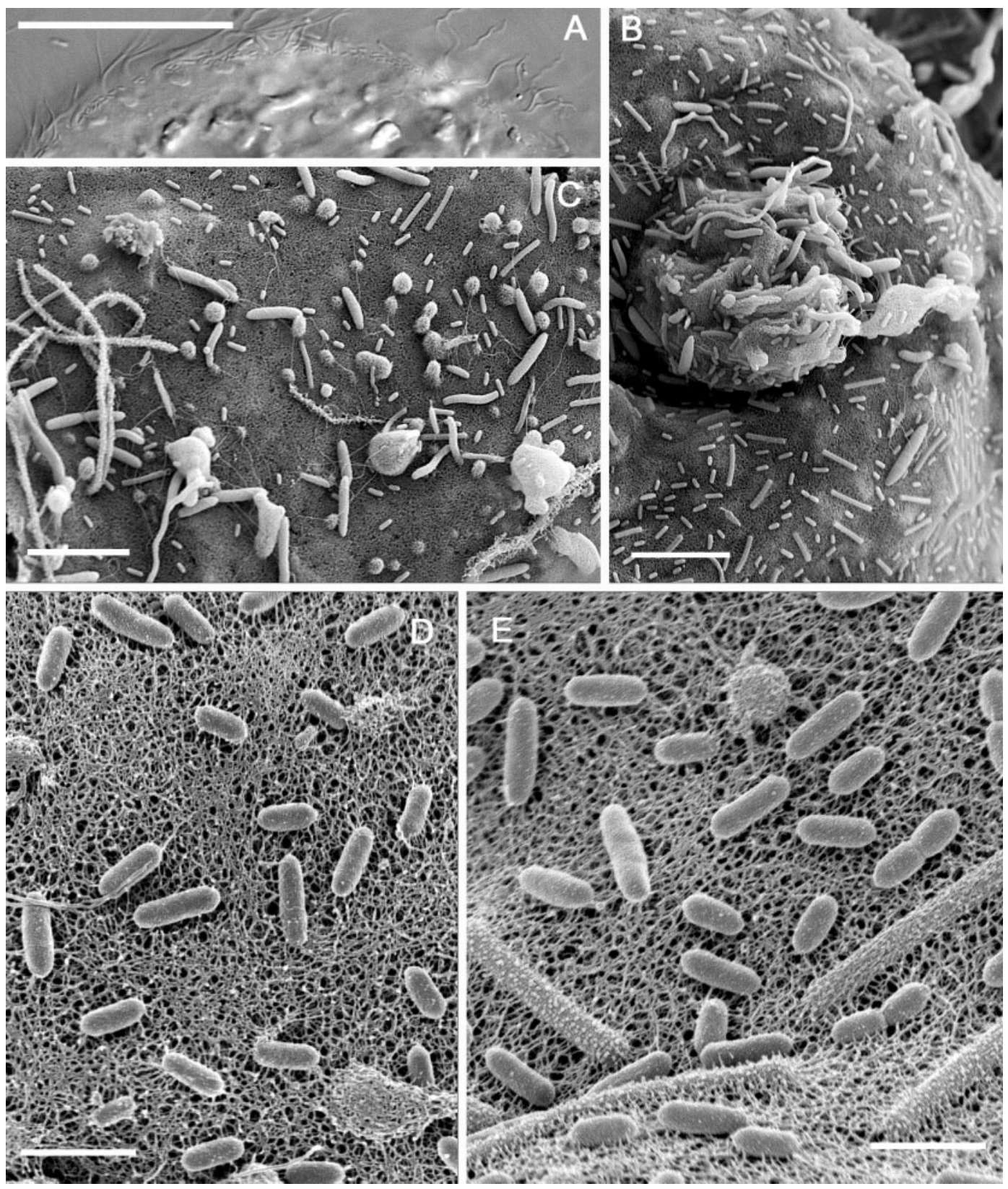

Fig. 2. Surface details of Calonympha chia sp. nov. (a) Differential interference contrast light micrograph with glancing optical section of cell surface showing rod-shaped bacteria. (b, c) SEM of the posterior of the cell showing considerable diversity of adherent bacterial morphotypes. (b) At least three morphotypes of rod-shaped bacteria are scattered at an even spacing across the cell surface. The protruding axostylar bundle and three spirochaete-like bacterial cells can be seen. (c) The diversity of bacterial ectosymbionts includes coccoid forms. Four emergent flagella can be seen to the left. (d, e) Ultra-high magnification micrographs showing the fibrous appearance of the fixed glycocalyx with adherent bacteria. (e) Coccoid and longer rod-shaped ectosymbionts appear to be embedded within the glycocalyx. Bars, a, $30 \mu \mathrm{m} ; \mathrm{b}, \mathrm{c}, 5 \mu \mathrm{m} ; \mathrm{d}, \mathrm{e}, 1 \mu \mathrm{m}$.

symbiont community that does not include a member of the genus Calonympha (our observations; Yamin, 1979). Second, we characterized two additional sequences in our environmental PCR from a Devescovina sp. and an unidentified tritrichomonad that were nearly identical to sequences from Branke's surveys (GenBank accession nos
X97974 and Y08538, Fig. 3). Finally, we determined the molecular barcode of the host using the mitochondrial COII sequence and found the two termites' sequences were identical (this study; Desai et al., 2009). Altogether, these lines of evidence demonstrate that the BAM strain is $N$. castaneus and that the Branke (1997) study and the current 


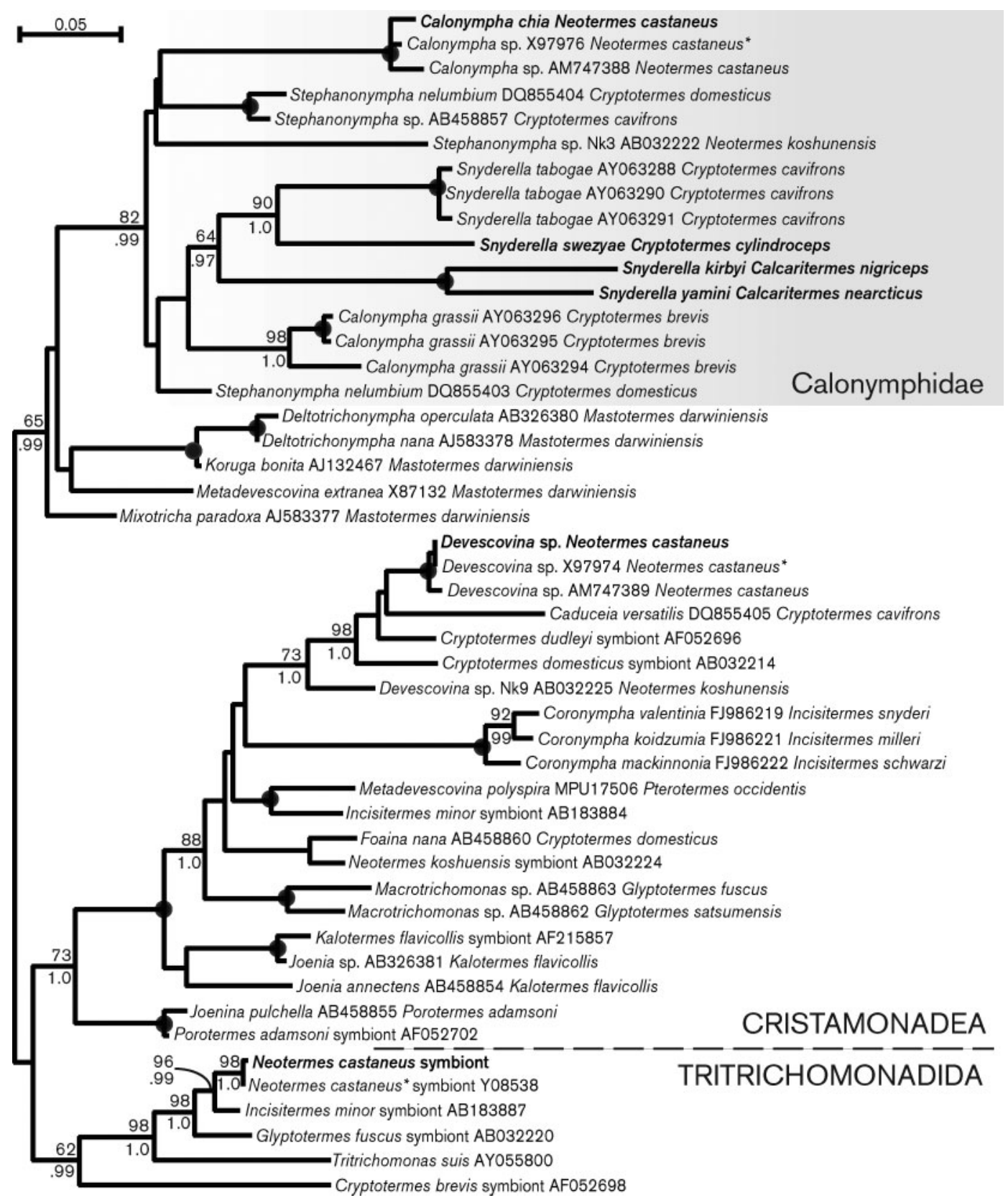

Fig. 3. ML phylogeny of SSU rRNA sequences from calonymphids, other cristamonads and close outgroup tritrichomonads. Numbers at nodes indicate ML bootstrap support as a percentage of the total in agreement out of 1000 replicates (above) and Bayesian posterior probability values (below). Filled circles indicate $100 \%$ bootstrap support and Bayesian posterior probability of 1 . Only bootstrap values $>65$ and posterior probabilities $>0.95$ are shown. New sequences determined in this study are indicated by bold type. Asterisks indicate sequences from $N$. castaneus from the Bundesanstalt für Materialforschung und -prüfung (BAM) erroneously attributed to $N$. jouteli, see text for details. Sequences AB032222 and AB032225, labelled 'Neotermes koshuensis parabasalian symbiont clone' in GenBank, were determined by FISH to be species of the genera Stephanonympha and Devescovina (Noël et al., 2007; Gerbod et al., 2002). Bar, 0.05 substitutions per site.

study document the same calonymphid species. Previous transmission electron microscopy (TEM) of symbionts from the BAM strain showed akaryomastigonts at the apex of the Calonympha sp. found in that gut (G. Brugerolle, personal communication), further supporting our observations and our conclusion that this novel species fits the morphological criteria for inclusion in the genus Calonympha.

The genus Calonympha has a somewhat turbulent history. A total of eight species names have been proposed since the 
genus was erected in 1905, but five of these were synonymized with the type species, Calonympha grassi, as their host termites were identified as Cryptotermes brevis, and two more underwent later name changes (Foà, 1905; Calkins, 1936; Brown, 1941; Kirby \& Margulis, 1994). Calonympha grassi is defined by the identity of its host, Cryptotermes brevis. Conversely, Calonympha angusta (Kirby 1994 ex. Calonympha grandis Brown 1941) is said to inhabit 16 termite species from five genera of termites from South and Central America (its type host is Rugitermes panamae), but it is morphologically indistinguishable from Calonympha grassi. In describing Calonympha angusta, Kirby noted that the continuum of variability observed in cell size, number, placement, size and shape of nuclei, and shape and size of the parabasal bodies, made it impossible to define the boundaries of populations, though he felt it likely that Calonympha angusta encompassed multiple species (Kirby \& Margulis, 1994). The third species of the genus Calonympha, Calonympha umbella (Kirby 1994 ex. Calonympha patella Brown 1941) from Neotermes tectonae, is only known from Indonesia. It is distinguished by an irregular arrangement of karyomastigonts and a more gradual branching of axostyles from the central bundle to the individual mastigonts (Kirby \& Margulis, 1994). The Calonympha species investigated here was isolated from N. castaneus, which is not the host of Calonympha umbella, Calonympha grassi or any of the hosts listed for Calonympha angusta. Furthermore, its SSU sequence was clearly distinct from that of Calonympha grassi, though no molecular data are yet available from representatives of Calonympha angusta. Accordingly, we propose a novel species, Calonympha chia sp. nov., because the flagella from karyo- and akaryomastigonts covering the apical half of the cell give it the appearance of a Chia Pet [an animal or human-shaped terracotta planter used to sprout chia (Salvia hispanica) in the USA; the chia sprouts and resembles the figure's fur or hair]. While it is clear that Calonympha chia sp. nov. and Calonympha grassi are distinct on the tree, it is impossible to conclude whether the genus Calonympha is monophyletic or not from this tree, since they are not separated by any strongly supported nodes (Fig. 3). If future molecular analyses confirm that the currently sampled Calonympha species are not monophyletic (see below), then the members of the Calonympha grassi clade will have priority and Calonympha chia sp. nov. will be transferred to a new genus. However, given the presence of Calonymphadefining features in the $N$. castaneus symbiont, the lack of support for their separation in phylogenetic trees and the poor sampling from this genus to date, we have conservatively retained this genus for the present.

\section{Snyderella kirbyi, Snyderella swezyae and Snyderella yamini spp. nov.}

We observed multinucleate, multiflagellate protists in the hindguts of two termites from Colombia, Calcaritermes nigriceps and Cryptotermes cylindroceps, and one termite from Florida, Calcaritermes nearcticus. In all three flagellates, the nuclei are randomly arranged, free in the cytoplasm and the anterior of the cell is covered with spiral rows of akaryomastigonts (Fig. 4). There is a distinct axostylar bundle that does not reach the cell's posterior. Several individuals of the symbiont from Calcaritermes nigriceps were seen in a stage of division (Fig. 4c, d). The internally scattered nuclei and lack of karyomastigonts place these flagellates in the genus Snyderella (Kirby, 1929).

The SSU sequences of all three symbionts were determined from isolated single cells or isolated pools of cells. In the case of the Calcaritermes nigriceps symbiont, ten pools of between one and 50 cells were isolated and the SSU was amplified in ten independent PCRs. A total of 15 clones were sequenced in both directions and differed at only 33 positions collectively. For the Cryptotermes cylindroceps symbiont, seven pools of 4-25 cells were isolated and a total of ten clones were sequenced from the seven independent PCRs. Again, the SSU sequences were found to differ at only 25 positions collectively. For the Calcaritermes nearcticus symbiont, 20 cells were isolated and five identical clones were sequenced from the single PCR product. In each case, a single clone sequence identical or nearly identical to the consensus was included in phylogenetic analyses and submitted to GenBank. In the phylogenetic analysis (Fig. 3 ), all three sequences were distinct from each other and from any known sequence, but they grouped closely with the existing Snyderella tabogae sequence, consistent with our identification. Furthermore, the Snyderella species isolated in this study from Cryptotermes cylindroceps branched with Snyderella tabogae from Cryptotermes brevis, while the two Snyderella species isolated from members of the genus Calcaritermes branched together, suggesting a certain amount of co-evolution between termites and their calonymphid symbionts.

Only four species of the genus Snyderella have been described previously. The type species, Snyderella tabogae (Kirby, 1929) was discovered in the hindgut of Cryptotermes longicollis from Taboga Island, Panama. Snyderella bandeirantium (de Mello, 1954b) from Cryptotermes brevis from an unspecified collection location in Brazil, differs from Snyderella tabogae by having only two basal bodies and two flagella per akaryomastigont and de Mello observed the nuclei to be placed somewhat more superficially. In Snyderella ypiranga (de Mello, 1954a) from Rugitermes rugosus, from the experimental station of Mount Alegre do Sul, Brazil, each axostylar filament branching off the central bundle leads to several akaryomastigonts rather than just one; there is no capitulum. Finally, Snyderella froilanoi from Neotermes arthurimulleri collected in Curitiba, Brazil (Kattar \& de Oliviera, 1973), bears two flagella per akaryomastigont, each axostyle joins only one akaryomastigont with a well-developed capitulum and the parabasal bodies are elongated.

For our newly discovered symbionts, morphological and molecular data indicate that all three belong to the genus Snyderella. All three are from different host termite species collected in different locations to any of the other four 

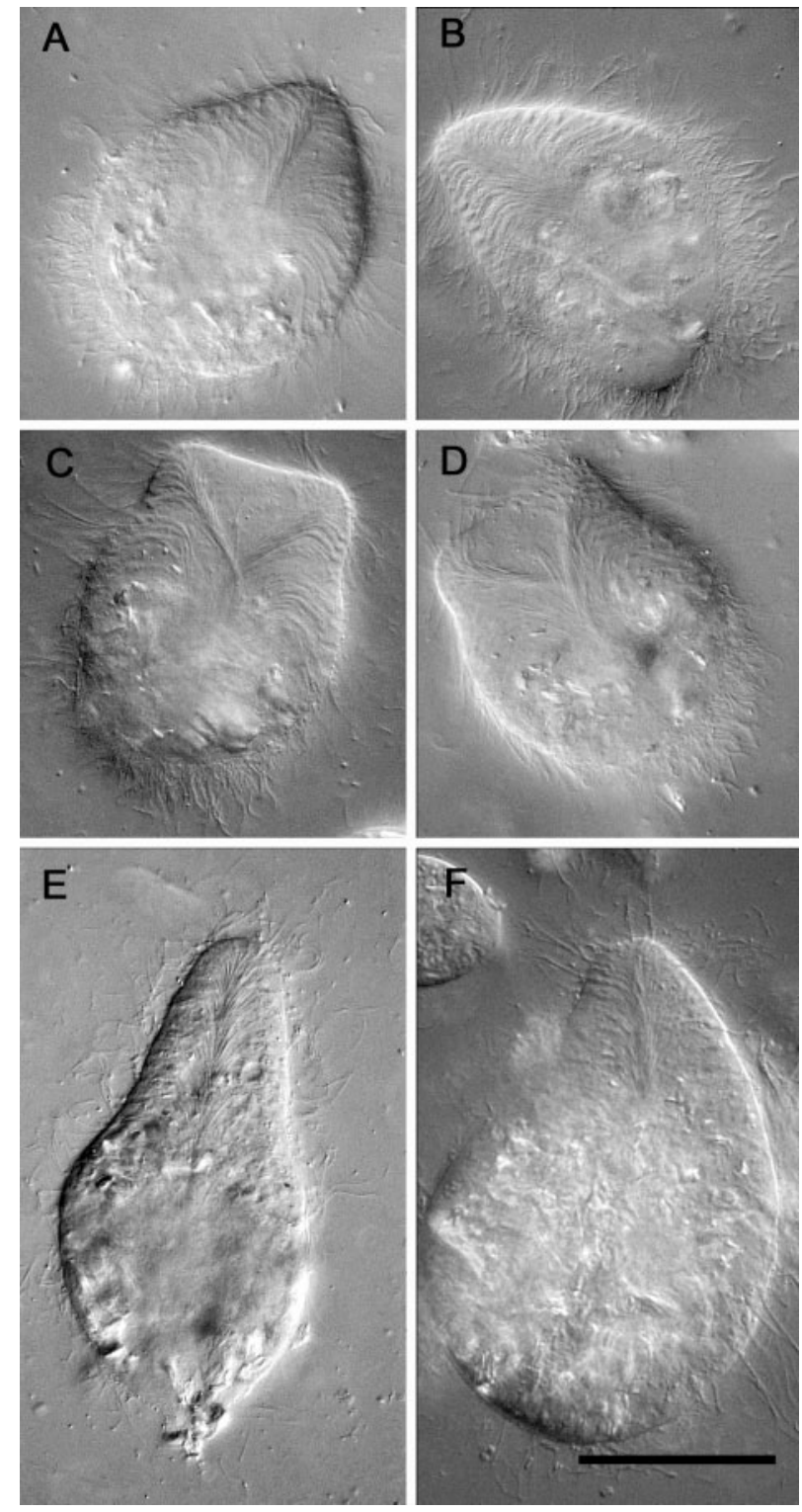

Fig. 4. Differential interference contrast light micrographs of species of the genus Snyderella described in this study. $(a-d)$ Snyderella kirbyi sp. nov. Side views of cell showing surface akaryomastigonts and ingested wood particles. The central axostylar bundle appears helically twisted. Spirochaetes or other bristleshaped bacteria adhere to the posterior of the cell. (c, d) Dividing cells. (e) Snyderella swezyae sp. nov. This cell is larger and more elongate than S. kirbyi sp. nov. (f) Snyderella yamini sp. nov., also a large elongate cell. The anterior portion of the axostylar bundle can be seen, though the posterior portion is obscured by wood particles that fill the expanded posterior of the cell. Bar, $50 \mu \mathrm{m}$.

described species. The SSU sequences of the novel species are considerably divergent from each other and from that of Synderella tabogae, though this sequence derives from a Snyderella sp. in Cryptotermes cavifrons, which is not the type host of Synderella tabogae and therefore may itself represent a distinct species of the genus Snyderella. Furthermore, we did not observe only two flagella per mastigont or axostylar filaments leading to multiple akaryomastigonts in either species, further ruling out their identity as Snyderella bandeirantium, Snyderella arthurimulleri or Snyderella ypiranga. The Snyderella species from Cryptotermes cylindroceps and Calcaritermes nearcticus were markedly larger and more elongated than the Snyderella sp. from Calcaritermes nigriceps (Fig. 4). Consequently, we propose Snyderella kirbyi sp. nov., from Calcaritermes nigriceps, Snyderella swezyae sp. nov., from Cryptotermes cylindroceps and Snyderella yamini sp. nov. from Calcaritermes nearcticus.

\section{Phylogeny of the family Calonymphidae}

In our molecular phylogeny of SSU rRNA sequences, as in others, the family Calonymphidae (here considered not to include the genus Coronympha) was monophyletic (Fig. 3). Previously published SSU and multigene phylogenies agree that this group is a part of the order Cristamonadida, along with the devescovinids, lophomonads and members of the genus Coronympha, and branches sister to a clade of members of the genera Koruga and Deltotrichonympha from the deepest-branching termite, Mastotermes darwiniensis (Gerbod et al., 2002; Noël et al., 2007; Noda et al., 2009; Cepicka et al., 2010). While the monophyly of the cristamonads in general and calonymphids specifically are both well established, relationships among and within calonymphid genera are less certain and in some cases the monophyly of genera is untested or questionable.

The genus Stephanonympha is the best studied in terms of molecular data (four sequences from three different termites) and number of species described (approx. 20). The two sequences from Stephanonympha nelumbium from Cryptotermes domesticus, its type host, group together with only a few polymorphisms. However, the other two species of this genus, from Neotermes koshuensis and Cryptotermes cavifrons, branch separately in our analyses and in previous analyses (Gerbod et al., 2002; Noël et al., 2007; Noda et al., 2009; Cepicka et al., 2010). This separation is not supported, so it remains possible that with deeper taxon sampling, the genus Stephanonympha may yet resolve itself as monophyletic (Lecointre et al., 1993; Heath et al., 2008), although there is no indication of this from current data. Moreover, the absence of akaryomastigonts is considered an ancestral state among calonymphids (Kirby, 1929), so the paraphyly of this state is perhaps unsurprising. Should this be borne out by additional data, the genus Stephanonympha would require a new, stricter definition, which will require more thorough study of the genus. In addition to the 17 recognized species for which no molecular data are available, many more species of the genus Stephanonympha probably inhabit the great number of kalotermitid species that have yet to be investigated, so this is clearly a genus where taxonomic changes are likely to be needed. 
Molecular data from the genus Snyderella were previously available only from Snyderella tabogae from Cryptotermes cavifrons (the type species for the genus is Snyderella tabogae from the type host Cryptotermes longicollis), so the monophyly of this genus has been untested by molecular data, a concern given the lack of evidence for monophyly of the genera Stephanonympha and Calonympha. Here we describe three novel species of Snyderella: Snyderella kirbyi sp. nov. from Calcaritermes nigriceps, Snyderella swezyae sp. nov. from Cryptotermes cylindroceps and Snyderella yamini sp. nov. from Calcaritermes nearcticus, and provide SSU sequences for all three. All three sequences branch with the Snyderella tabogae sequence with $64 \%$ bootstrap support and Bayesian posterior probability of 0.97 (Fig. 3 ), overall suggesting that the Snyderella species sampled here are monophyletic. The strong support for sisterhood of Snyderella species from the same host termite genus further suggests coevolution between Snyderella species and their kalotermitid hosts. In the converse situation to the genus Stephanonympha, the presence of only akaryomastigonts is considered to be a derived character, and therefore may be a good synapomorphy for the genus (Kirby, 1929).

Molecular data exist for two species of the genus Calonympha: Calonympha grassi, the type species from the type host Cryptotermes brevis, where some sequence diversity exists (Fig. 3), and a Calonympha sp. reported to be from $N$. jouteli, but which observations here and from other groups have shown is actually $N$. castaneus. The Calonympha sequences from $N$. castaneus, which we have here described as Calonympha chia sp. nov., form a distinct group branching distantly from those of Calonympha grassi, although once again this separation is not strongly supported (Fig. 3). The presence of both karyomastigonts and akaryomastigonts, which are defining characteristics of this genus, in both Calonympha phylotypes may be an indication that these characteristics have arisen independently from a Stephanonympha-like ancestor with only karyomastigonts, in keeping with Kirby's interpretation of the genus Calonympha as an intermediate stage in a phyletic progression beginning with all karyomastigonts in the genus Stephanonympha and culminating with complete nuclear dissociation in the genus Snyderella (Kirby, 1929).

Because molecular data are lacking for the majority of described calonymphid species, and many kalotermitid host species remain uninvestigated, it is clear that an understanding of the diversity and evolution of this group awaits further sampling. In particular, the five recognized genera for which no molecular data are available should be sampled to assess their validity, monophyly and placement within the group. The genus Diplonympha (Grassi, 1917) was reported to have two nuclei per karyomastigont, but doubts about this observation and the validity of this genus have been expressed in the literature (Kirby, 1947; Brugerolle \& Lee, 2000). The genus Metastephanonympha (de Mello \& de Brito, 1929) was reported to carry only two flagella per karyomastigont, but may in fact be a synonym of the genus Stephanonympha (Kirby, 1947). The genus Prosnyderella is said to show the same axostylar branching pattern as the genus Snyderella, but has karyomastigonts interspersed with the akaryomastigonts (Dolan \& Kirby, 2002). The genera Criconympha and Gyronympha were both described from Rugitermes panamae and are distinguished by an empty apex with no akaryomastigonts (Criconympha) and by a tightly ordered ring of karyomastigonts at the apex in a tuft (Gyronympha) (Dolan \& Kirby, 2002). Ultimately the stability of genus-defining characters and the patterns of character evolution in the group, in particular whether the Calonympha-type morphology has arisen multiple times from a Stephanonympha-like ancestor, await molecular and morphological characterization of many more calonymphids.

\section{TAXONOMIC SYNOPSIS}

\section{Calonympha chia Gile and Keeling sp. nov.}

Type host. Neotermes castaneus.

Type locality. N 25.17608 W 80.36945, Dagny Johnson Park, Key Largo, FL, USA.

Host collection. University of Florida termite collection, accession number FL3191. Collector R. H. Scheffrahn. Collected 9 April 2008.

Diagnosis. Multinucleate flagellates from the hindgut of $N$. castaneus. Cells with apical spirals of mastigonts and nuclei associated with the hindmost ring or rings of mastigonts (karyomastigonts). Distinct from other species of the genus Calonympha by type host and locality and distinct SSU sequence.

Hapantotype. SEM stub deposited at the Beaty Biodiversity Museum, University of British Columbia, Vancouver, Canada, under accession number MI-PR104.

Gene sequence. SSU rRNA GenBank accession number HQ215836.

Etymology. The many clustered flagella covering the anterior half of the cell and the usual absence of spirochaetes on the cell's posterior, give this species the appearance of a Chia Pet.

\section{Snyderella kirbyi Gile and Keeling, sp. nov.}

Type host. Calcaritermes nigriceps.

Type locality. N 11.1256 W 74.11972, above Minca, Colombia. 
Host collection. University of Florida termite collection, accession number CO548. Collector R. H. Scheffrahn. Collected 5 June 2009.

Diagnosis. Multinucleate flagellates from the hindgut of Calcaritermes nigriceps. Cells with characteristics of the genus Snyderella, including spirals of akaryomastigonts covering the anterior half to two-thirds of the cell, nuclei randomly dispersed within the endoplasm and axostyles gathered in a bundle in the central axis of the cell. Distinct from other species of the genus Snyderella by type host and distinct SSU sequence.

Hapantotype. Unstained prepared slide deposited at the Beaty Biodiversity Museum, University of British Columbia, Vancouver, Canada, under accession number MI-PR105.

Gene sequence. SSU rRNA GenBank accession number HQ215837.

Etymology. This species is named after the distinguished protistologist, Harold Kirby, who made significant contributions to the study of parabasalid symbionts of termites, including the establishment of the genus Snyderella in 1929.

\section{Snyderella swezyae Gile and Keeling, sp. nov.}

Type host. Cryptotermes cylindroceps.

Type locality. N 9.86610 W 75.15836, NW San Jacinto, Colombia.

Host collection. University of Florida termite collection, accession number CO373. Collector R. H. Scheffrahn. Collected 3 June 2009.

Diagnosis. Multinucleate flagellates from the hindgut of Cryptotermes cylindroceps. Cells with characteristics of the genus Snyderella, including spirals of akaryomastigonts covering the anterior half to two-thirds of the cell, nuclei randomly dispersed within the endoplasm, and axostyles gathered in a bundle in the central axis of the cell. Distinct from other species of the genus Snyderella by type host and distinct SSU sequence.

Hapantotype. Unstained prepared slide deposited at the Beaty Biodiversity Museum, University of British Columbia, Vancouver, Canada, under accession number MI-PR106.

Gene sequence. SSU rRNA GenBank accession number HQ215838.

Etymology. This species is named after the distinguished protistologist, Olive Swezy, whose contributions to the study of flagellate symbionts of termite guts included the recognition that trichomonads and hypermastigotes belong to the same clade.

\section{Snyderella yamini Gile and Keeling, sp. nov.}

Type host. Calcaritermes nearcticus.

Type locality. N 27.99531 W 82.11748, Plant City, FL, USA.

Host collection. University of Florida termite collection, accession number FL3527. Collector R. H. Scheffrahn. Collected 26 August 2010.

Diagnosis. Multinucleate flagellates from the hindgut of Calcaritermes nearcticus. Cells with characteristics of the genus Snyderella, including spirals of akaryomastigonts covering the anterior half to two-thirds of the cell, nuclei randomly dispersed within the endoplasm and axostyles gathered in a bundle in the central axis of the cell. Distinct from other species of the genus Snyderella by type host and distinct SSU sequence.

Hapantotype. Unstained prepared slide deposited at the Beaty Biodiversity Museum, University of British Columbia, Vancouver, Canada, under accession number MI-PR107.

Gene sequence. SSU rRNA GenBank accession number HQ593144.

Etymology. This species is named after the protistologist, Michael Yamin, whose compiled tables of parabasalid species and their hosts continue to be of great reference value for research into the diversity and evolution of symbiotic parabasalids.

\section{ACKNOWLEDGEMENTS}

We would like to thank Harris Falconer for technical assistance. All termite specimens from Colombia were collected under Permiso No. 21 del 26 de Noviembre de 2009, Ministerio de Ambiente, Vivienda y Desarrollo Territorial, Dirección de Licencias, Permisos y Trámites Ambientales, Expediente: IDB0053, Elabor: Yeison F. Rodriguez V. This work was supported by the Natural Science and Engineering Research Council of Canada (NSERC) (grant 227301) to P. J. K., and an NSERC postgraduate doctoral fellowship to G. H. G. P. J. K. is a Fellow of the Canadian Institute for Advanced Research and a Senior Scholar of the Michael Smith Foundation for Health Research.

\section{REFERENCES}

Branke, J. T. (1997). Phylogenetische und morphologische Charakterisierung pro- und eukaryontischer Mikroorganismen aus dem Maüse- und Termitendarm. $\mathrm{PhD}$ thesis, Universität Ulm, Germany.

Brown, H. E. (1941). Flagellates of the genus Calonympha from termites. PhD thesis, University of Georgia, GA, USA.

Brugerolle, G. (1991). Flagellar and cytoskeletal systems in amitochondrial flagellates: Archamoeba, Metamonada and Parabasala. Protoplasma 164, 70-90.

Brugerolle, G. \& Lee, J. J. (2000). Phylum Parabasalia. In An Illustrated Guide to the Protozoa, pp. 1196-1250. Edited by J. J. Lee, G. Leedale \& P. Bradbury. Lawrence, KS: Allen Press Inc. 
Calkins, G. N. (1936). Some polymastigote and hypermastigote flagellates from Puerto Rican termites. PR J Public Health Trop Med 12, 169-187.

Cepicka, I., Hampl, V. \& Kulda, J. (2010). Critical taxonomic revision of Parabasalids with description of one new genus and three new species. Protist 161, 400-433.

Deane, J. A., Hill, D. R. A., Brett, S. J. \& McFadden, G. I. (1998). Hanusia phi gen. et. sp. nov. (Cryptophyceae): Characterization of 'Cryptomonas sp. $\Phi$ '. Eur J Phycol 33, 149-154.

de Mello, I. F. (1954a). Contribution à l'étude des microparasites de termites brésiliens. II. Un nouveau Calonymphide, "Snyderella ypiranga" sp. n., de "Rugitermes rugosus" (Hagen 1858). Rev Bras Biol 14, 71-78 (in French).

de Mello, I. F. (1954b). Sur un nouvelle espèce de Calonymphide du termite brèsilien Cryptotermes sp. recolté dans la ville de Campinas. An Inst Med Trop (Lisb) 11, 339-360 (in French).

de Mello, I. F. \& de Brito, J. (1929). Sur trois espèces de Devescovina parasites de l'intestin d'un termite récolté à Damaum (Inde Portugaise) et de la complexité de leur appareil kinétoplastique. Arq Esc Méd Cirurg Nova Goa ser. A 5, 693-706 (in French).

Desai, M. S., Strassert, J. F. H., Meuser, K., Hertel, H., IkedaOhtsubo, W., Radek, R. \& Brune, A. (2009). Strict cospeciation of devescovinid flagellates and Bacteroidales ectosymbionts in the gut of dry-wood termites (Kalotermitidae). Environ Microbiol.

Dolan, M. F. \& Kirby, H. (2002). Gyronympha, Prosnyderella and Criconympha, three new genera of calonymphids (Parabasalia: Trichomonadida) from wood-eating termites. Eur J Protistol 38, 73-81.

Foà, A. (1905). Due nuovi flagellati parassiti. Rend Reale Accad Lincei 14, 542-546.

Gerbod, D., Noël, C., Dolan, M. F., Edgcomb, V. P., Kitade, O., Noda, S., Dufernez, F., Ohkuma, M., Kudo, T. \& other authors (2002). Molecular phylogeny of parabasalids inferred from small subunit rRNA sequences, with emphasis on the Devescovinidae and Calonymphidae (Trichomonadea). Mol Phylogenet Evol 25, 545-556.

Grassi, B. (1917). Flagellati viventi nei termiti. Mem Reale Accad Lincei 12, 331-394.

Grassi, B. \& Foà, A. (1911). Intorno ai protozoi dei termitidi. Rend Reale Accad Lincei 20, 725-741.

Harper, J. T., Gile, G. H., James, E. R., Carpenter, K. J. \& Keeling, P. J. (2009). The inadequacy of morphology for species and genus delineation in microbial eukaryotes: an example from the parabasalian termite symbiont coronympha. PLoS ONE 4, e6577.

Heath, T. A., Hedtke, S. M. \& Hillis, D. M. (2008). Taxon sampling and the accuracy of phylogenetic analyses. J Syst Evol 46, 239-257.

Hongoh, Y., Sato, T., Noda, S., Ui, S., Kudo, T. \& Ohkuma, M. (2007). Candidatus Symbiothrix dinenymphae: bristle-like Bacteroidales ectosymbionts of termite gut protists. Environ Microbiol 9, 26312635.

Ikeda-Ohtsubo, W., Desai, M., Stingl, U. \& Brune, A. (2007). Phylogenetic diversity of 'Endomicrobia' and their specific affiliation with termite gut flagellates. Microbiology 153, 3458-3465.

Janicki, C. (1911). Zur Kenntnis des Parabasalapparat bei parasitischen Flagellaten. Biol Zentbl 31, 321-330 (in German).

Kambhampati, S. \& Smith, P. T. (1995). PCR primers for the amplification of four insect mitochondrial gene fragments. Insect $\mathrm{Mol}$ Biol 4, 233-236.

Katoh, K., Misawa, K., Kuma, K. \& Miyata, T. (2002). MAFFT: a novel method for rapid multiple sequence alignment based on fast Fourier transform. Nucleic Acids Res 30, 3059-3066.
Kattar, M. R. \& de Oliviera, G. M. F. (1973). Duas novas espécies de protozoarios flagelados simbiontes de térmita. Acta Biol Paranense 2, 113-119 (in Portuguese).

Keeling, P. J. (2002). Molecular phylogenetic position of Trichomitopsis termopsidis (Parabasalia) and evidence for the Trichomitopsiinae. Eur J Protistol 38, 279-286.

Kirby, H. (1929). Snyderella and Coronympha two new genera of multinucleate flagellates from termites. Univ Calif Publ Zool 31, 417432.

Kirby, H. (1939). Two new flagellates from termites in the genera Coronympha Kirby, and Metacoronympha Kirby, new genus. Proc Calif Acad Sci 22, 207-220.

Kirby, H. (1947). Flagellate and host relationships of trichomonad flagellates. J Parasitol 33, 214-228.

Kirby, H. \& Margulis, L. (1994). Harold Kirby's symbionts of termites: Karyomastigont reproduction and calonymphid taxonomy. Symbiosis 16, 7-63.

Lecointre, G., Philippe, H., Vân Lê, H. L. \& Le Guyader, H. (1993). Species sampling has a major impact on phylogenetic inference. Mol Phylogenet Evol 2, 205-224.

Maddison, D. R. \& Maddison, W. P. (2003). MacClade 4: Analysis of phylogeny and character evolution, version 4.08. Sunderland, MA: Sinauer Associates, Inc.

Medlin, L., Elwood, H. J., Stickel, S. \& Sogin, M. L. (1988). The characterization of enzymatically amplified eukaryotic 16S-like rRNA-coding regions. Gene 71, 491-499.

Noda, S., Mantini, C., Bordereau, C., Kitade, O., Dolan, M. F., Viscogliosi, E. \& Ohkuma, M. (2009). Molecular phylogeny of parabasalids with emphasis on the order Cristamonadida and its complex morphological evolution. Mol Phylogenet Evol 52, 217224.

Noël, C., Noda, S., Mantini, C., Dolan, M. F., Moriya, S., DelgadoViscogliosi, P., Kudo, T., Capron, M., Pierce, R. J. \& other authors (2007). Molecular phylogenetic position of the genera Stephanonympha and Caduceia (Parabasalia) inferred from nuclear small subunit rRNA gene sequences. J Eukaryot Microbiol 54, 9399.

Ohkuma, M., lida, T., Ohtoko, K., Yuzawa, H., Noda, S., Viscogliosi, E. \& Kudo, T. (2005). Molecular phylogeny of parabasalids inferred from small subunit rRNA sequences, with emphasis on the Hypermastigea. Mol Phylogenet Evol 35, 646-655.

Posada, D. \& Crandall, K. A. (1998). MODELTEST: testing the model of DNA substitution. Bioinformatics 14, 817-818.

Ronquist, F. \& Huelsenbeck, J. P. (2003). MrBayes 3: Bayesian phylogenetic inference under mixed models. Bioinformatics 19, 15721574.

Simon, C., Frati, F., Beckenbach, A., Crespi, B., Liu, H. \& Flook, P. (1994). Evolution, weighting, and phylogenetic utility of mitochondrial gene sequences and a compilation of conserved polymerase chain reaction primers. Ann Entomol Soc Am 87, 651-701.

Stamatakis, A. (2006). RAxML-VI-HPC: maximum likelihood-based phylogenetic analyses with thousands of taxa and mixed models. Bioinformatics 22, 2688-2690.

Swofford, D. L. (2002). PAUP*: Phylogenetic analysis using parsimony (and other methods), version 4. Sunderland, MA: Sinauer Associates.

Trager, W. (1934). The cultivation of a cellulose-digesting flagellate, Trichomonas termopsidis, and of certain other termite protozoa. Biol Bull 66, 182-190.

Wirth, T., Le Guellec, R. \& Veuille, M. (1999). Directional substitution and evolution of nucleotide content in the cytochrome oxidase II 
gene in earwigs (dermapteran insects). Mol Biol Evol 16, 16451653.

Yamin, M. A. (1979). Flagellates of the orders Trichomonadida Kirby, Oxymonadida Grassé, and Hypermastigida Grassi \& Foà reported from lower termites (Isoptera families Mastotermitidae, Kalotermitidae, Hodotermitidae, Termopsidae, Rhinotermitidae, and Serritermitidae) and from the wood-feeding roach Cryptocercus (Dictyoptera: Cryptocercidae). Sociobiology 4, 5-119. 